\title{
PHENODYNAMICS OF Solanum mauritianum SCOP. IN A PLANTATION FOR SUBTROPICAL FOREST RESTORATION
}

\author{
Marcos Lubke ${ }^{1 *}$, Lucas Lubke ${ }^{1}$, Bruno Jan Schramm Corrêa ${ }^{2}$, Marciele Filippi ${ }^{3}$, Fernando Campanhã Bechara ${ }^{1}$ \\ ${ }^{1}$ Universidade Tecnológica Federal do Paraná, Unidade de Ensino, Pesquisa e Extensão em Restauração Ecológica, Dois Vizinhos, Paraná, \\ Brasil -*marcoslubke@ hotmail.com; lucas_lubke@hotmail.com; bechara@utfpr.edu.br \\ ${ }^{2}$ Universidade do Estado de Santa Catarina, Programa de Pós-graduação em Produção Vegetal, Lages, Santa Catarina, Brasil - \\ brschramm74@gmail.com \\ ${ }^{3}$ Universidade Tecnológica Federal do Paraná, Coordenação de Ciências Biológicas, Dois Vizinhos, Paraná, Brasil - \\ marcielefilippi@utfpr.edu.br
}

Received for publication: 02/10/2019 - Accepted for publication: 27/08/2020

\begin{abstract}
Resumo
Fenodinâmica de Solanum mauritianum Scop. em uma plantação para restauração de floresta subtropical. O objetivo deste estudo foi avaliar a fenodinâmica de Solanum mauritianum Scop. em uma plantação florestal para verificar o comportamento ecológico dessa espécie em condição de restauração. Foram observadas 12 árvores ao longo de 24 meses, considerando-se rebrotação, floração, frutificação e desfolhamento. As fenofases foram correlacionadas com as variáveis climáticas - fotoperíodo, temperatura máxima, média, mínima e precipitação - através de correlação de Pearson. A espécie exibiu comportamento ao longo do ano, altamente sincrônico, tanto na floração quanto na frutificação. O florescimento ocorreu de janeiro a dezembro, sendo observados botões florais simultaneamente com frutos maduros, atingindo uma dispersão máxima em fevereiro. Temperaturas abaixo de $10^{\circ} \mathrm{C}$ e geadas inibiram a brotação de folhas, promovendo um pico de queda de folhas em março e junho. A disponibilidade permanente de recursos como flores e frutos e a resiliência das fenofases vegetativas em resposta a fortes geadas fazem de $S$. mauritianum uma espécie adaptada de alto potencial ecológico para uso em projetos de restauração na região.
\end{abstract}

Palavras-chave: fenologia; fumeiro-bravo; Mata atlântica.

\begin{abstract}
We evaluated the phenodynamics of Solanum mauritianum Scop. in a forest plantation to check the ecological behavior of this species in restoration condition. Twelve trees were observed over 24 months, according to regrowth, flowering, fruiting and defoliation. The phenophases were correlated with the photoperiod, climatic variables, maximum, average, minimum temperature and precipitation through Pearson's correlation. The species exhibited over the year highly synchronic, flowering and fruiting. The flowering occurred from January to December, with floral buds being observed simultaneously with ripe fruits, reaching a maximum dispersion in February. Temperatures below $10^{\circ} \mathrm{C}$ and frosts inhibited the leaf re-sprouts, promoting a leaf deciduous peak in March and June. The permanent availability of resources as flowers and fruits and the resilience of vegetative phenophases in response to severe frosts make $S$. mauritianum an adapted species of highly ecological potential to be used in regional restoration projects.

Keywords: phenology; wild tobacco; Atlantic forest.
\end{abstract}

\section{INTRODUCTION}

Phenology is the study of the stages of plant life cycle events and their temporal occurrence throughout the year, according to the periodic biological events related to repetitive changes and interrelations in abiotic and biotic factors (MORELLATO et al, 2010). According to Alves and Silva (2013), precipitation, minimum temperature, photoperiodism, and solar radiation would be related to the phenophases. Seasonality, periodism and synchrony are also reported in phenological studies, where the rate of leaf loss is determined by the severity of the season (MORELLATO et al., 2000). The understanding of phenodynamics is crucial for ecological processes since plants have their own phenological rhythms that depend on environmental conditions to be activated. Variations in the climatic patterns interfere in blooming, fructification, and in the vegetative stages of a particular species. The blooming and fruiting seasons may differ between individuals of the same species and between regions (FELIPPI et al., 2012).

Phenological calendars can be applied to forest management, especially in plantations that aims to recover degraded areas where food resources availability must be provided throughout the year to maintain the associated pollinator and disperser fauna (FELIPPI et al., 2012; MORELLATO et al., 2016). Among the genus Solanum (Solanaceae), the most prevalent species for subtropical forest restoration is Solanum mauritianum Scop. commonly known as wild tobacco (fumeiro-bravo). This species is potential to be employed to recover degraded areas because of its rusticity, rapid growth, dense crown, and capacity to feed pollinators besides dispersing birds and bats. The individuals can reach approximately $15 \mathrm{~m}$ in height and over $20 \mathrm{~cm}$ in DBH. It reaches adulthood in

FLORESTA, Curitiba, PR, v. 51, n. 2, p. 439-446, abril/jun 2021.

Lubke, M. et.al.

ISSN eletrônico 1982-4688

DOI: 10.5380/rf.v51 i2. 69523 
two to three years and usually reaches senescence at no more than 15 years of age. Considered a short-lived pioneer species, it produces a large amount of leaf litter that consequently increases organic matter in the soil and provides edaphic conditions for the colonization of demanding species in fertility, which makes this a species of ecological and silvicultural importance (RUSCHEL; NODARI, 2011).

We aimed to evaluate the phenodynamics of $S$. mauritianum in a forest plantation to check the ecological behavior of this species, in restoration condition.

\section{MATERIAL AND METHODS}

The phenological observations were conducted for 24 months from January 2013 to December 2014 in the farm of the Federal University of Technology - Paraná state, municipality of Dois Vizinhos, Brazil $\left(25^{\circ} 41^{\prime} 37^{\prime}\right.$ ' $\mathrm{S} ; 5^{\circ} 06^{\prime} 07^{\prime \prime} \mathrm{W}$; altitude ranging from 495 to $504 \mathrm{~m}$ ). This is a montane subtropical forest in an Araucaria forest with influence of semi-deciduous forest (ecotone). The region climate is Cfa according to the Köppen, with no dry season and average annual temperatures between $19^{\circ} \mathrm{C}$ and $20^{\circ} \mathrm{C}$, with occurrences of frost at least every two years, especially from June to August. Frosts in the area may also occur prematurely at the end of May, or even late at the beginning of September. The average annual precipitation is $2.044 \mathrm{~mm}$. August and March are the driest months and October is the rainiest one (ALVARES et al., 2017; STOLARSKI et al., 2018).

The study area was a 3-years experimental restoration plantation arranged in four plots (repetitions) of 40 X $54 \mathrm{~m}$, where 360 tree seedlings of 70 species were spaced in 3 X $2 \mathrm{~m}$ (see VOGEL et al., 2015). Three plants of S. mauritianum in each plot were monitored, totaling 12 selected trees, randomly chosen from 54 individuals planted (plants at the edge of the plots were not considered). The selected trees were monitored every two weeks using binoculars to observe the presence and intensity of each phenophase: leaves resprouting and decidousity, flowering and fruiting were quantified.

The flower budding was considered when appeared even small, shiny, light green buds. Leaf loss was established as the change of leaf color, from green to yellow or orange, or when the leaf fell due to wind, as well the presence of leaves on the ground, next to the plant (Figure 1).

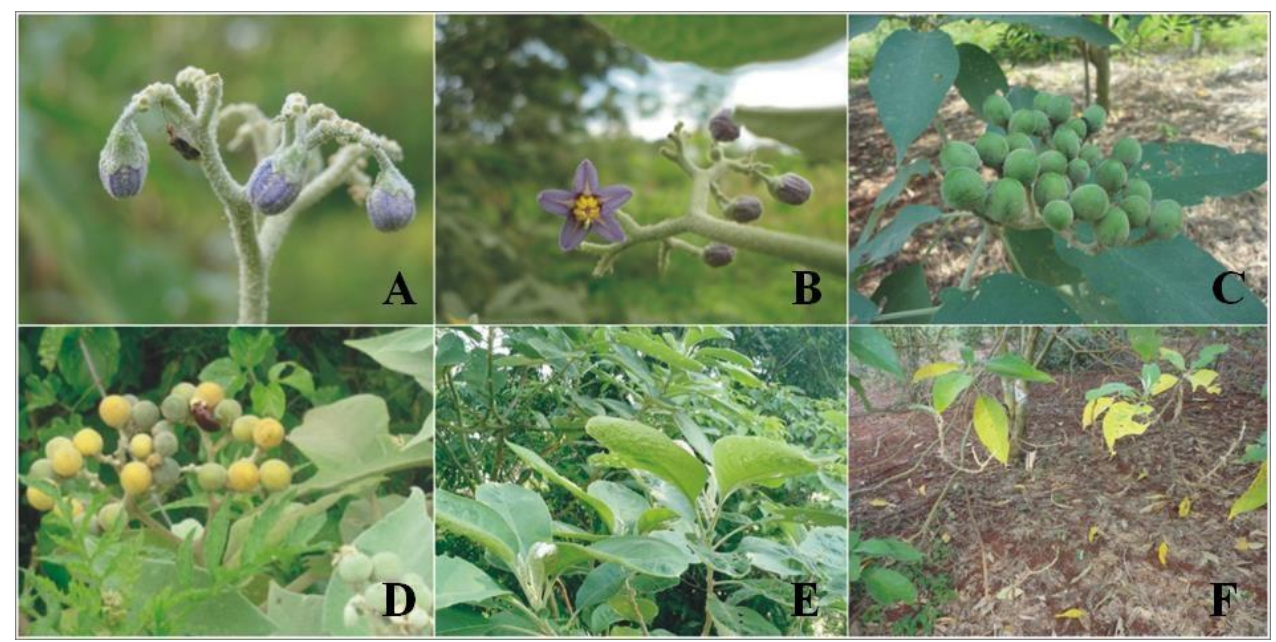

Figure 1. Phenophases of Solanum mauritianum Scop.: (A) flower budding; (B) flower anthesis; (C) immature fruit; (D) ripe fruit; (E) resprouting; (F) decidousity.

Figura 1. Fenofases de Solanum mauritianum Scop.: (A) botões florais; (B) flores em antese; (C) frutos imaturos; (D) frutos maduros; (E) brotação; (F) desfolhamento.

Flowering was considered as the period in which the trees were with pre-anthesis buds and opened flowers (Figure 1A, Figure 1B). For fruiting, the presence of developing and mature fruit, light green in color with shades of yellow (Figure 1a; 1d) and low resistance when gently squeezed (soft fruits) were considered.

The phenophases were quantified using the method of Fournier (MORELLATO et al., 2010), which proposes categories ranging from 0 to 4 for each phenophase: (0) absence of phenological event; (1) presence of the event ranging from 1 to $25 \%$; (2) the presence of the event ranging from 26 to $50 \%$; (3) the presence of the event ranging from 51 to $75 \%$; and (4) the presence of the event ranging from 76 to $100 \%$. The Fournier Index (FI) was calculated by: $\mathrm{FI}=\left(\sum \mathrm{F} .100\right) / 4$. N, where $\mathrm{F}=$ note of the category; $\mathrm{N}=$ number of sample units.

We verified the synchrony of the phenophases between individuals of the sampled population, according to Morellato et al. (2010), where, for each phenophase, the occurrence of less than $20 \%$ of individuals was

FLORESTA, Curitiba, PR, v. 51, n. 2, p. 439-446, abril/jun 2021.

Lubke, M. et.al. 
considered asynchronous; the occurrence of 20 to $60 \%$, synchronous; and over than $60 \%$, highly synchronous. The frequency of reproductive events was classified as annual, sub-annual or supra-annual and it was divided according to Newstrom et al. (1994) into: brief annual, with a maximum duration of four weeks; intermediate annual, lasting from two to three months; and extended annual, lasting over three months. The astronomical day length (photoperiod) was calculated according to the solar declination for the municipality of Dois Vizinhos, and climate data for the study period (average, peak, and minimum temperature and precipitation) were obtained from the meteorological station located in the farm.

Data were tabulated using Excel ${ }^{\mathrm{TM}}$ software, and the relationship of the phenophases with the photoperiod and climatic variables was verified using Pearson's correlation coefficient (r) by Software R ${ }^{\mathrm{TM}}$. The data were subjected to a normality test and the Box-Cox transformation was run for the variables that did not provide this assumption.

\section{RESULTS}

A peak was observed in the number of sunshine hours per day (photoperiod) in December, and the daily average in 2013 and 2014 was $13.56 \mathrm{~h}$. The lowest average of sunshine-hours per day occurred in June (10.8 h). The lowest and the highest monthly average minimum temperatures were $10.8^{\circ} \mathrm{C}$ in July 2013 and $21.4^{\circ} \mathrm{C}$ in December 2014, respectively. Frosts were observed in July and August 2013, which caused the reduction of degrees Celsius in the average monthly minimum temperature (Figure 2).

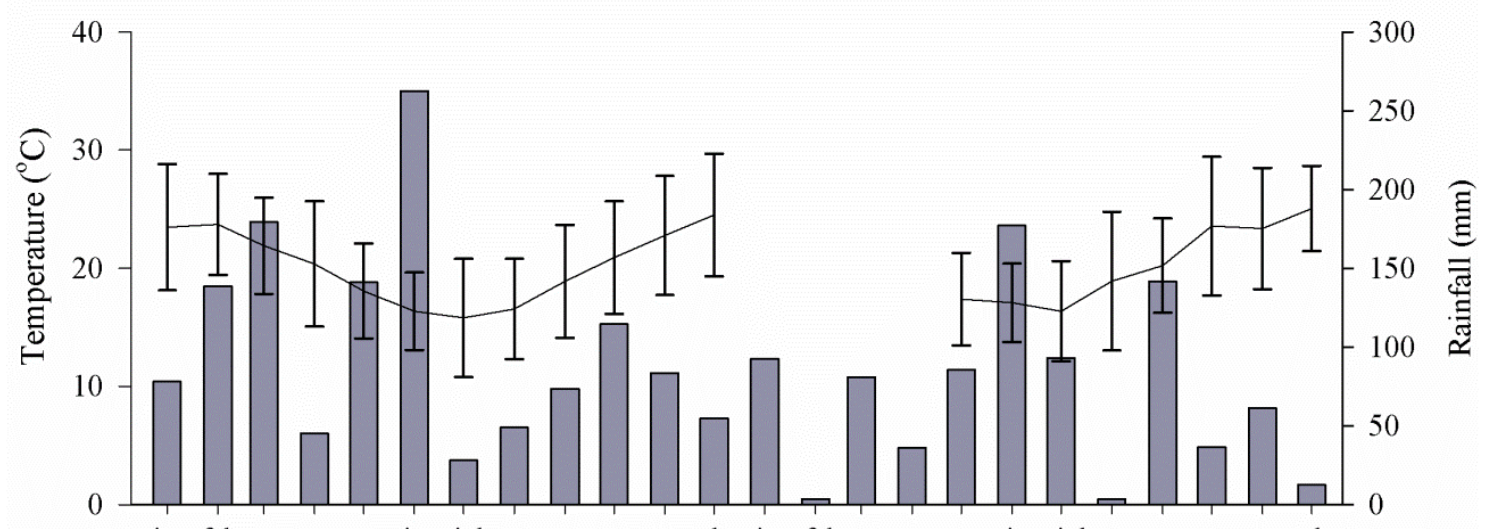

jan feb mar apr may jun jul aug sep oct nov dec jan feb mar apr may jun jul aug sep oct nov dec

2014

Figure 2. Meteorological variables (temperature means and rainfall) registered in Dois Vizinhos - PR state, Brazil, during the period of study. (Source: INMET/UTFPR).

Figura 2. Variáveis meteorológicas (médias de temperatura e chuvas) registradas em Dois Vizinhos-PR, durante o período de estudo. (Fonte: INMET/UTFPR).

The monthly averages for the lowest and highest maximum temperatures were $19.6{ }^{\circ} \mathrm{C}$ in June 2013 , and $30.1^{\circ} \mathrm{C}$ in January 2014 , respectively. The months with the highest total monthly precipitation were June 2013 $(525 \mathrm{~mm})$ and June 2014 (354 mm), while the months with the lowest total monthly precipitation were February and August 2014 (7 mm). During the 24 months of observations (Figure 3), the emergence of the individual leaf shoots of S. mauritianum was continuous, with the exception of August, 2013, when the species was affected by frosts. Between January and March, there was a peak in the vegetative phenophase, where the intensity of growth was $79.1 \%$ for 2013 and $75 \%$ for 2014 . For the remaining months, the level of emission of leaves dropped, reaching around $20 \%$ during the winter season.

FLORESTA, Curitiba, PR, v. 51, n. 2, p. 439-446, abril/jun 2021.

Lubke, M. et.al. 


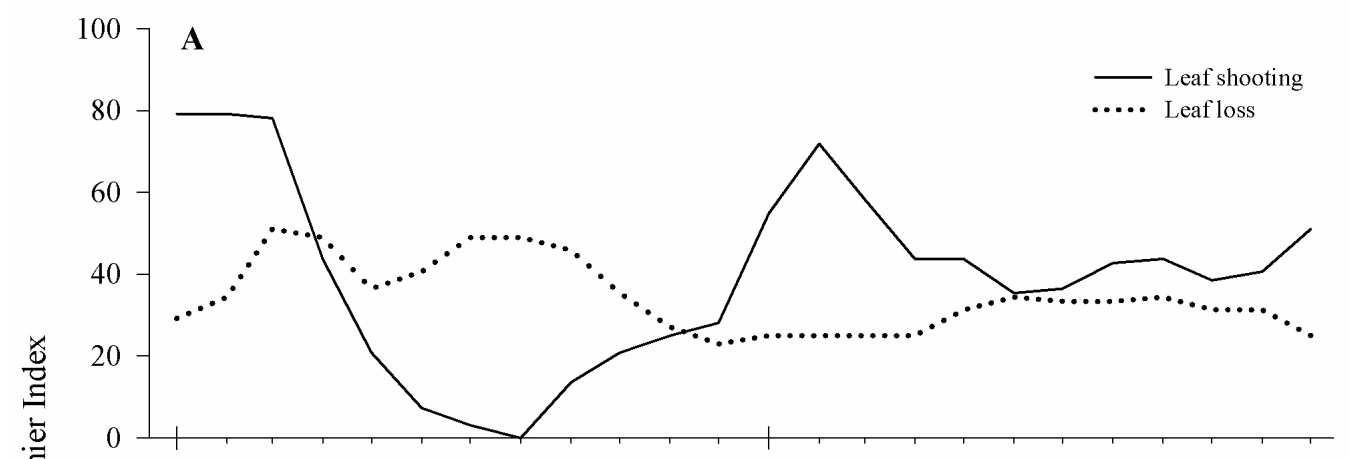

jan feb mar apr may jun jul aug sep oct nov dec jan feb mar apr may jun jul aug sep oct nov dec

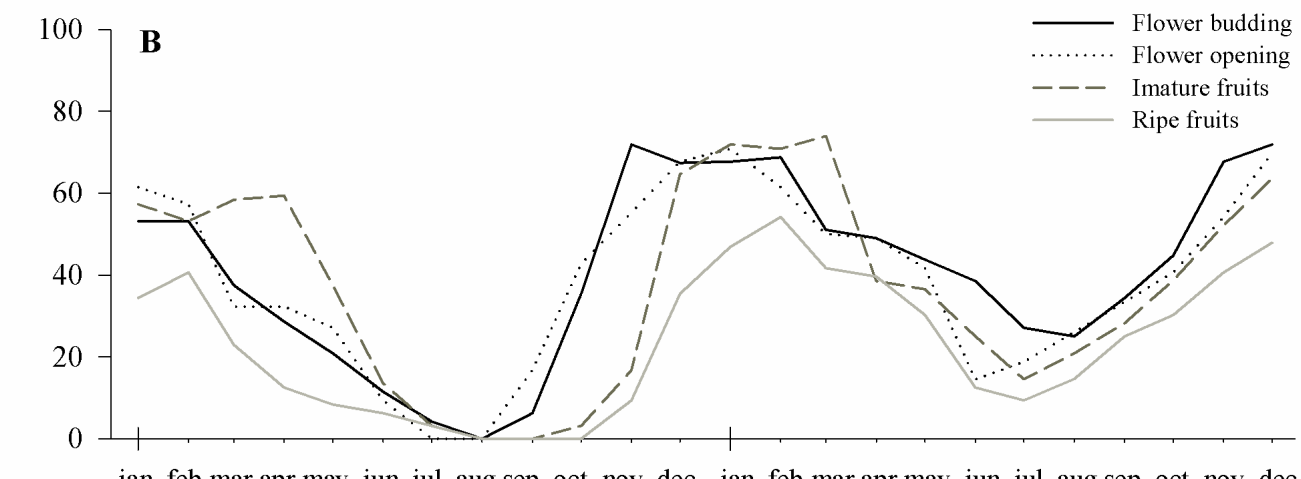

jan feb mar apr may jun jul aug sep oct nov dec jan feb mar apr may jun jul aug sep oct nov dec

2014

Figure 3. Phenodynamics of Solanum mauritianum Scop.: (A) Percentage (\%) of leaves shooting and decidousity;

(B) Intensity (\%) of the reproductive phenophases.

Figura 3. Fenodinâmica de Solanum mauritianum Scop.: (A) Porcentagem (\%) de brotamento e desfolhamento;

(B) Intensidade (\%) das fenofases reprodutivas

According to Table 1, the vegetative phenophase presented a significant correlation with temperature and the photoperiod. In the foliar change pattern, the development and emission of vegetative shoots coincided with the occurrence of longer and warmer days. It was observed that budding decreased and leaf dropping increased during the colder months (June to August).

Table 1. Pearson`s correlation (r) between the Fournier Index for reproductive and vegetative phenophases of Solanum mauritianum Scop. and meteorological variables.

Tabela 1. Correlação de Pearson (r) entre o Índice de Fournier para fenofases reprodutivas e vegetativas de Solanum mauritianum Scop. e variáveis meteorológicas.

\begin{tabular}{|c|c|c|c|c|c|c|}
\hline Phenophases & & T. min. $\left({ }^{\circ} \mathrm{C}\right)$ & T. avg. $\left({ }^{\circ} \mathrm{C}\right)$ & Max. $\left({ }^{\circ} \mathrm{C}\right)$ & Precipitation (mm) & Day length \\
\hline \multirow{4}{*}{ Vegetative } & \multirow{2}{*}{ Leaf shooting } & 0.63261 & 0.61525 & 0.56417 & -0.02890 & 0.38047 \\
\hline & & $P(<0.0001)$ & $P(<0.0001)$ & $P(<0.0001)$ & $P(0.8454)$ & $P(0.007)$ \\
\hline & \multirow{2}{*}{ Leaf loss } & -0.53474 & -0.51887 & -0.47583 & 0.09773 & -0.46805 \\
\hline & & $P(<0.0001)$ & $P(0.0001)$ & $P(0.0006)$ & $P(0.5087)$ & $P(0.0007)$ \\
\hline \multirow{8}{*}{ Reproductive } & \multirow{2}{*}{ Flower budding } & 0.81802 & 0.80187 & 0.74050 & -0.12928 & 0.73086 \\
\hline & & $P(<0.0001)$ & $P(<0.0001)$ & $P(<0.0001)$ & $P(0.3812)$ & $P(<0.0001)$ \\
\hline & \multirow{2}{*}{ Flower opening } & 0.83859 & 0.83312 & 0.77917 & -0.15888 & 0.78912 \\
\hline & & $P(<0.0001)$ & $P(<0.0001)$ & $P(<0.0001)$ & $P(0.2808)$ & $P(<0.0001)$ \\
\hline & \multirow{2}{*}{ Imature fruits } & 0.73344 & 0.70865 & 0.64776 & -0.08804 & 0.45912 \\
\hline & & $P(<0.0001)$ & $P(<0.0001)$ & $P(<0.0001)$ & $P(0.5518)$ & $P(0.001)$ \\
\hline & \multirow{2}{*}{ Ripe fruits } & 0.77407 & 0.74027 & 0.66816 & -0.18888 & 0.52533 \\
\hline & & $P(<0.0001)$ & $P(<0.0001)$ & $P(<0.0001)$ & $P(0.1985)$ & $P(<0.0001)$ \\
\hline
\end{tabular}

FLORESTA, Curitiba, PR, v. 51, n. 2, p. 439-446, abril/jun 2021. 
The emission of flower buds occurred during the 24 months of observation (January to December), with the exception of August 2013 (Figure 3B). Pearson's correlation (Table 1) revealed that the emergence of reproductive buds was affected by the low temperatures in July 2013 (Figure 2), when we recorded the lowest monthly average $\left(10.8^{\circ} \mathrm{C}\right)$, the lowest minimum temperature $\left(-1.8^{\circ} \mathrm{C}\right)$, and occurrence of frosts, which probably have affected this phenophase in August. The highest precipitation $(525 \mathrm{~mm})$ in June (2013) did not benefit the emergence of flower buds, but the drop in temperature negatively affected the phenophase, as observed in the positive correlation $(\mathrm{r}=0.81802)$. Classified here as "extended annually", the $S$. mauritianum flowering exhibited high synchronicity since the proportion of individuals sampled in a given event was over $60 \%$. This phenophase was more intense in the highest temperature periods (November to February), with peaks of intensity exceeding $70 \%$. According to Table 1, the increased flowering rates were correlated with the photoperiod and with the maximum temperature, except for rainfall, which showed no significant relationship. The amount of flowers produced in the winter varied from one year to the next, demanding for longer monitoring.

The fruits initiated development after the floral anthesis event, and from January to March all the individuals exhibited a $70 \%$ intensity of fruits (Figure 3B). The presence of ripe fruits persisted throughout the year except from August to October 2013, probably due to the frosts in July of the same year, as observed in other phenophases. The climax of the phenophase occurred in February and reached $54.1 \%$ in 2014. We noted that from July to October of the first year (2013), the plants had only $1.5 \%$ of developing fruits, while for the same period in the second year (2014) the index was over $15 \%$. Low temperatures probably resulted in a negative influence on the phenophases of $S$. mauritianum. Finally, we stress the presence of different phenological stages (leaves resprouting and flower budding, leaf dropping, flowers in anthesis, immature and ripe fruits) occurring simultaneously (Figure 3).

\section{DISCUSSION}

The vegetative growth of $S$. mauritianum occurred during every month of the year (Figure 3A). However, this growth exhibited changes in intensity, with a peak during the warmer months and a decline in the winter. According to Morellato et al. (2000) the changes in vegetative phenophases are associated with an adaptive strategy to the subtropical environment in which the species is found, where the metabolic activity decreases or increases and triggers the leaves falling.

The significant correlation between the vegetative phenophases and temperature and the photoperiod was observed through the development and emission of vegetative shoots. According to Morellato et al. (2000), light is one of the factors that determines the entry or not of many species re-sprouting. Indirectly, light changes the internal rhythm of plants and provides energy for cell growth in the plant tissue that trigger the issuance of shoots. This issuance occurs when the phytochrome (PR) in the leaves of the plant perceives the ideal combination of number of hours of light and dark (VIEIRA et al., 2010). In a similar manner to light, temperature affects the photochemical reactions, which reduces the photosynthetic rate of the plant and mainly decreases activity of the meristematic regions.

The results found here differ from those reported by Marques and Oliveira (2004) in the restinga forest (coastal plain vegetation) of Ilha do Mel - PR state, where the leaf shedding of S. mauritianum mainly occurred from October and December, immediately followed by leaf emission from November to January. According to Ruschel and Nodari (2011), this difference could be associated with the study site and the climate changes that occurred during the years monitored. The phenological events in tree species are highly responsive to the conditions of the environment, which stresses the importance of observing the behavior of each species in ecological restoration projects.

The increased emission rate of leaves in the spring promotes the renewal of leaves in the canopy. Consequently, as the temperature increases in the summer, the leaves serve as protection from the sunrays protecting the soil and probably acting as regeneration nuclei by facilitation mechanisms (REIS et al., 2010). Similarly, during the cold season, the accumulation of litter can help maintain and protect the soil, as well the seedling and seed bank of more demanding species in fertility or sensitive to lower temperatures.

Flowering also was considered extended annually according to the classification of Newstron et al., (1994), and exhibited high synchrony (MORELLATO et al., 2010). The flowering period for the study region was similar to the period described by Marques et al. (2004) for southern Brazil. These authors noted the occurrence of peak blooms during the months with high temperature and a longer photoperiod, as observed in our study.

According to Soares et al. (2008) in natural areas of Rio Grande do Sul state, southern Brazil, it is possible to find flowering species during most of the year. The same author highlighted the characteristic of continuous flowering for other species of Solanum, such as S. atropurpureum, S. capsicoides, S. aff. guaraniticum, and S. paniculatum. The behavior of $S$. mauritianum in our experimental plantations resembles (except for July and

FLORESTA, Curitiba, PR, v. 51, n. 2, p. 439-446, abril/jun 2021.

Lubke, M. et.al. 
August) its behavior observed in other natural forests, which suggests the success of the restoring management to provide food resources.

The supply of its zoophilic flowers for most of the year, especially in years without frost events, in the case of plantations for ecological restoration, increases the ecological importance of the species, especially for pollinators attracting. Willmer (2011), highlighted that the availability of flowers over a long period increases the chances of different pollinator groups settling in the area, which contributes to ecological relations in the ecosystem.

Similar to what occurred during the vegetative phenophases, the weather conditions influenced the flowering rates (Table 1, Figure 3B): there was a peak in this phenophase during the hottest period with longer days. Marchioretto et al. (2007), also observed an increase in the flowering of S. mauritianum, although with less intensity than in our study. Morellato et al. (2016) stressed the importance of sufficient light to induce the reproductive process. The life cycle of the species (or part of it) is possibly regulated by the photoperiod since the phenophases were favored by the action of light. This demonstrates the response of plants to variations in the duration of the day and in the process of flower induction. Therefore, positively influencing the phenological state of the species.

Furthermore, the amount of flowers produced in the winter varied from one year to the next. These phenotypic variations or even reproductive irregularity between consecutive years can be linked to genetic and environmental factors, as well as precipitation and temperature, and can express changes in morphology, anatomy, and the photosynthetic rate, among other factors like global climate changes (FELIPPI et al., 2012). The fruiting phenophase (Figure 3B) was maintained for most the year, with a peak of maturation in February and a decrease after the coldest season. Thus, the low temperatures seem to have a negative influence on this phenophase. The presence of fruit along a prolonged period characterizes $S$. mauritianum as extended annual fruiting, and the high incidence of trees containing fruits in the phenophase classifies it as synchronous (MORELLATO et al., 2010) (Figure 3B).

Athayde et al. (2009) found that the regular distribution of precipitation throughout the year contributed to the better distribution of fruiting along the year in a riparian forest in Rio Grande do Sul state. Climate and also the microclimate changes, such as the abundance of pollinators driven by habitat fragmentation and edge effects, can also alter the reproductive phenology of plants (MORELATTO et al., 2016). All phenological events occurred simultaneously for S. mauritianum (Figure 3), providing flowers, fruits and biomass production throughout most of the year, what is extremely positive for fauna attraction (CAMPOS et al., 2012; PAULINHO-NETO, 2014) and forest recovering. S. mauritianum is also able to become mature and close the canopy (providing regeneration and facilitating niches for animals) in two to three years, although this speed will probably vary with frosts events in the subtropics. Besides, the orthodox seeds of S. mauritianum (RUSCHEL; NODARI, 2011), maintain the fruits maturation for a longer period, probably enriching the seed bank and forest regeneration.

The phenological events observed in this study were similar to those recorded by Marques and Oliveira (2004), Marques et al. (2004), and Marchioretto et al. (2007) in southern Brazil. These findings support the idea that seasonal phenology of $S$. mautitianum in subtropical Brazil is triggered mainly by temperature and photoperiod, especially in years of harsh winters with severe frosts, which differs from the phenological models of the rest of Atlantic Forest, where the phenophases are governed mainly by the annual variation of rainfall.

\section{CONCLUSIONS}

- Temperatures below $10^{\circ} \mathrm{C}$ inhibited sprouting and favoured the leaf loss of S. mauritianum, demonstrating its deciduous behavior. Similarly, the photoperiodism and higher temperatures increased the flowering and fruiting.

- The peak of seed dispersals occurred in February and the greatest quantity of seeds can be collected from January to March.

- The flowering and fruiting of $S$. mauritinaum was throughout the year, occurring from January to December, except in frosty times. Leaves and flower buds can be concurrently found with flowers and developing or ripe fruits in 3 -y-old trees.

\section{REFERENCES}

ALVARES, C. A.; SENTELHAS, P. C.; STAPE, J. L. Modeling monthly meteorological and agronomic frost days, based on minimum air temperature, in Center-Southern Brazil. Theoretical and Applied Climatology, Viena, v. 113, n. 3, p. 177 - 191, 2017.

FLORESTA, Curitiba, PR, v. 51, n. 2, p. 439-446, abri1/jun 2021.

Lubke, M. et.al. 
ALVES, M. V. P.; SILVA, J. C. S. Fenologia de Emmotun nitens (Benth.) (Miers Icacinaceae) na Reserva Ecológica Cerradão - Embrapa Cerrados, Planaltina, DF. Revista Verde de Agroecologia e Desenvolvimento Sustentável, Pombal, v. 8, n.1, p. 125 - 31, 2013.

ARAUJO, R. G.; ANDREOLI, R. V.; CANDIDO, L. A.; KAYANO, M. T.; SOUZA, R. A. F. A influência do evento El Niño - Oscilação Sul e Atlântico Equatorial na precipitação sobre as regiões norte e nordeste da América do Sul. Acta Amazonica, Manaus, v. 43, n.4, p. 469 - 480, 2013.

ATHAYDE, E. A.; GIEHL E. L. H.; BUDKE, J. C.; GESING, J. P. A.; EISINGER, S. M. Fenologia de espécies arbóreas em uma floresta ribeirinha em Santa Maria, sul do Brasil. Revista Brasileira de Biociências, Porto Alegre, v. 7, n. 1, p. 43 - 51, 2009.

BAUER, D.; GOETZ, M. N. B.; MULLER, A.; SCHMITT, J. L. Fenologia de três espécies de Myrsine 1. em floresta secundária semidecídua no Sul do Brasil. Revista Árvore, Viçosa, v. 36, n. 5, p. 859 - 868, 2012.

BUISSON, E.; ALAVARADO, SWANNI T.; LE STRADIC, S.; MORELLATO, L. P. C. Plant phenological research enhances ecological restoration. Restoration Ecology, Washington, v. 25, p. 164 - 171, 2017.

CAMPOS, W. H.; NETO, A. M.; PEIXOTO, H. J. C.; GODINHO, L. B.; SILVA, E. Contribuição da fauna silvestre em projetos de restauração ecológica no Brasil. Pesquisa Florestal Brasileira, Colombo, v. 32, n. 72, p. 429 - 440, 2012.

FELIPPI, M.; MAFFRA, C. R. B.; CANTARELLI, E. B.; ARAÚJO, M. M.; LONGHI, S. J. Fenologia, morfologia e análise de sementes de Apuleia leiocarpa (Vogel) J. F. Macbr. Ciência Florestal, Santa Maria, v. 22, n.3, p. 477 - 491, 2012.

MARCHIORETTO, M. S.; MAUHS, J.; BUDKE, J. C. Fenologia de espécies arbóreas zoocóricas em uma floresta psamófila no sul do Brasil. Acta Botanica Brasilica, Belo Horizonte, v. 21, p. 193 - 201, 2007.

MARQUES, M. C. M. M.; OLIVEIRA, P. E. A. Fenologia de espécies do dossel e do sub-bosque de duas Florestas de Restinga na Ilha do Mel, sul do Brasil. Revista Brasileira de Botânica, São Paulo, v. 27, n.4, p. 713 - 723 , 2004.

MARQUES, M. C. M.; ROPER, J. J.; SALVALAGGIO, A. P. B. Phenological patterns among plant life-forms in a subtropical forest is southern Brazil. Plant Ecology, New York, v. 173, p. 203 - 213, 2004.

MOREllato, L. P. C.; ALBERTON, B.; ALVARADO, S.T.; BORGES, B.D.; BUISSON, E.; CAMARGO, M.G.G.; CARSTENSEN, D.W.; ESCOBAR, D. F.; LEITE, P.; MENDOZA, I.; PERES, C.A.; ROCHA, N.M.W.B.; SILVA, T. S. F.; SOARES N. C.; STAGGEMEIER, V. G.; VARGAS, B. C; Linking plant phenology to conservation biology. Biological Conservation, Washington, v. 195, p. 60 - 72, 2016.

MORELlATO, L. P. C.; TALORA, D. C.; TAKAHASI, A.; BENCKE, C. C.; ROMERA, E. C.; ZIPPARRO, V. B. Phenology of Atlantic Rain Forest trees: a comparative study. Biotropica, Lawrence, v. 32, p. 811 - 823, 2000.

MORELlATO, L.P.C.; CAMARGO, M.G.G.; D’EÇA-NEVES, F.F.; LUIZE, B. G.; MANTOVANI, A.; HUDSON, I. The influence of sampling method, sample size, and frequency of observations on plant phenological patterns and interpretation in tropical forest trees. In: HUDSON, I. L.; KEATLEY, M. R. Phenological research: methods for environmental and climate change analysis. Amsterdam: Springer, 2010, 356 p.

NEWSTROM, L. E.; FRANKIE, G. W.; BAKER, H. G. A new classification for plant phenology based on flowering patterns in lowland tropical rain forest at La Selva, Costa Rica. Biotropica, Lawrence, v. 26, n. 2, p. $141-159,1994$.

PAULINHO-NETO, H. F.; NAKANO-OLIVEIRA, E.; ASSIS, M. M.; MEDEIROS, R. P.; VASCONCELOSNETO, J. Frugivory by Sturnira lilium bats (Phyllostomidae) on Solanum mauritianum (Solanaceae) in southeastern Brazil. Studies on Neotropical Fauna and Environment, London, v. 48, n. 3, p. 183 - $189,2014$.

REIS, A.; BECHARA, F. C.; TRES, D. R. Nucleation in tropical ecological restoration. Scientia Agricola, Piracicaba, v. 67, n.2, p. 244 - 250, 2010.

RUSCHEL, A. R.; NODARI, R. O. Solanum mauritianum. In: CORADIN, L.; SIMINSKI, A.; REIS, A. Espécies Nativas da Flora Brasileira de Valor Econômico Atual ou Potencial: Plantas para o Futuro - Região Sul. Brasília: MMA, 2011, 934 p.

FLORESTA, Curitiba, PR, v. 51, n. 2, p. 439-446, abril/jun 2021.

Lubke, M. et.al. 
SOARES, E. L. C.; VIGNOLI-SILVA, M.; VENDRUSCULO, G. S.; THODE, V. A.; SILVA, J. G.; MENTZ, L. A. A família Solanaceae no Parque Estadual de Itapuã, Viamão, Rio Grande do Sul, Brasil. Revista Brasileira de Biociências, Porto Alegre, v. 6, n. 3, p. 177 - 188, 2008.

STOLARSKI, O. C.; GORENSTEIN, M. R.; LUBKE M.; LUBKE L.; O’CONNOR, H. P.; BECHARA, F. C. Trema micrantha (L.) Blume. em plantações para restauração ecológica: desenvolvimento inicial na Floresta Subtropical Brasileira. Ciência Florestal, Santa Maria, v. 28, v. 3, p. 1217 - 1229, 2018.

VIEIRA, E. L.; SOUZA, G. S.; SANTOS, A. R.; SILVA, J. S. Manual de Fisiologia Vegetal. São Luis: EDUFMA, 2010, $640 \mathrm{p}$.

VOGEL, H. F.; CAMPOS, J. B.; BECHARA, F. C. Early bird assemblages under different subtropical forest restoration strategies in Brazil: passive, nucleation and high diversity plantation. Tropical Conservation Science, Washington, n. 8, n. 4, p. 912 - 939, 2015.

WILLMER, P. Pollination in Different Habitats. In: WILLMER, P. Pollination and Floral Ecology. Princeton: Princeton University Press, 2011, 828 p.

FLORESTA, Curitiba, PR, v. 51, n. 2, p. 439-446, abril/jun 2021. 